"A holistic view of the use of corporate culture conveyed by internal marketing for enhancing stability, sustainability and consistency in service quality"

AUTHORS J.A.R. Botha

J.A.R. Botha (2016). A holistic view of the use of corporate culture conveyed by

ARTICLE INFO internal marketing for enhancing stability, sustainability and consistency in service quality. Investment Management and Financial Innovations, 13(3-1), 248257. doi:10.21511/imfi.13(3-1).2016.11

DOI http://dx.doi.org/10.21511/imfi.13(3-1).2016.11

RELEASED ON Friday, 23 September 2016

JOURNAL

"Investment Management and Financial Innovations"

FOUNDER

LLC "Consulting Publishing Company "Business Perspectives"

NUMBER OF REFERENCES

0

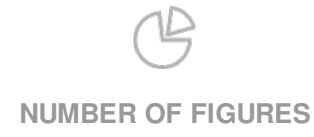

0

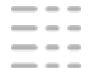

NUMBER OF TABLES

0

(C) The author(s) 2022. This publication is an open access article. 


\title{
A holistic view of the use of corporate culture conveyed by internal marketing for enhancing stability, sustainability and consistency in service quality
}

\begin{abstract}
While businesses worldwide are aiming increasingly on the sustainability in various business areas, customer service is by nature not consistent and stable, because it is delivered by human beings and, therefore, subject to their imperfections and influences on them. This can result in unstable, unsustainable and unpredictable service delivery. This article describes the corporate culture/service quality conceptualization as a basis for overcoming this by embedding and implementing the stability and sustainability of corporate culture to enhance the stability and sustainability of quality of service. This conceptual study demonstrates that a well-planned and maintained corporate culture, based on quality service delivery goals, is able to do exactly that under the initiative of the leadership. Although there are many articles referring to service quality, very few of them succeed in bringing sufficient aspects into account to be able to form a holistic image of enhancing stability, sustainability and consistency in service quality. Existing models and approaches were combined in a holistic conceptual approach.
\end{abstract}

Keywords: service quality, corporate culture, stability, sustainability, customer perception, perceived quality, expectations, ACSI, internal marketing, relationship marketing, CSP, profit service chain.

JEL Classification: L8, M14, M31, M30.

\section{Introduction}

"The bitterness of poor quality remains long after low pricing is forgotten!" This is the familiar slogan ascribed to the well-known Gucci family (also ascribed to people such as Charles Royce the cofounder of Rolls Royce, Benjamin Franklin and Leon M Cautillo) (Wisdom on demand). This emphasizes the recognition by influential people regarding the lasting image or impression of the quality experience. It's well known that customer service is not always stable and sustainable mainly due to the fact that service is delivered by human beings and, therefore, subject to the fallibilities and inconsistency of human nature. Sustainable service quality requires the full commitment of frontline employees with direct contact with customers (Ekmekci, 2009 and Liang, Tseng and Lee, 2010). Contact sessions with frontline employees become the customer's holistic experience of the entire customer service of the organization (Beaujean et al., 2006; Zeithaml, Bitner and Gremler, 2009). Kotler and Keller $(2012$, pp. 18, 151) explains thoroughly the importance of the holistic marketing concept and orientation. Holistic marketing acknowledges that everything matters in marketing and that a broad, integrated perspective is often necessary.

Service quality is fluctuating by nature and a client of a business may experience that different frontline employees (people behind the counter) treat them differently, and that the same person behind the counter may treat him/her differently on different occasions or different days or even at different times

(c) J.A.R. Botha, 2016.

J.A.R. Botha, Dr., D.Com., BProc (SA), Senior Lecturer, Department of Marketing and Retail Management, University of South Africa, South Africa. on the same day (Verna, 2012). Good consistent service quality is important, because it can be linked directly to the profitability of a business as explained by the model of the service profit chain (Heskett, Jones, Loveman, Sasser Jr. and Schlesinger, 2008).

A service is by nature directly linked to the individual delivering the service (Cambra-Fiero, Melero-Polo and Vazquez-Carrasco, 2014, pp. 69-71). This notion gives rise to the problem that the quality of services, derived by different individuals or even by the same individual under different circumstances, may differ widely (Cerasale, 2005 p, 181). An organization can only ensure stable and sustainable service quality, in line with business objectives, if it is impregnated by a positive corporate culture that is by nature a consistent behavioral aspect in organizations over the long term (Watkins, 2013).

\section{Main aim and objective}

The objective of this article is to construct a conceptualization of impregnating service delivery quality culture with an integrated marketing system to provide stability and sustainability in service quality. Corporate culture is integrated with the components of the marketing support system and the components of service quality. The article is aimed at describing marketing components that can link corporate culture effectively to the output of stable and sustainable service quality.

\section{The conceptualization of the research}

The conceptualization in this article proclaims that the planning of a stable sustainable customer service starts off by the management taking initiative and 
intervening purposefully in uncontrolled disrupting influences on service quality (Ruchlin, Dubbs, 2004, pp. 47-53) in the following three ways:

- Plan a corporate culture in which the organizational objectives and core values are embodied.

- Get the personnel engaged in the corporate culture by transferring the ideas to them as primary part of the organizations internal marketing.

- Imprint and sustain the components of the corporate culture on a continuous basis by means of relationship marketing between the top management and the employees.

\section{The unique characteristics and problems of services}

Marketers identify the following as being the main characteristic of services (Kotler and Keller, 2007): intangibility; inseparability of production and consumption; perishability; and heterogeneity (or variability). This article is especially interested in the last mentioned characteristic, namely variability, because services are performed by humans with different characteristics such as skills, knowledge, motivation, training and circumstances. Humans are also not consistent in nature meaning that the same person will not always be able to repeat the same quality of service every day (China Construction Bank, 2007 and Verna, 2012). But the customer requires sustainability.

Consumer satisfaction generally determines whether the organization providing the service met the consumers' needs and perceptions (Lervik-Olsen and Johnson, 2003, p. 2). Service delivery satisfaction can follow immediately on service delivery and/or it can be cumulative (Ghandi and Kang, 2012, pp. 129-133). Customer satisfaction over the long term, enable organizations to build sustainable competitive advantages, a sustainable service quality and brand culture. This will ultimately contribute towards better customer loyalty and profitability, because it diminishes the consumers' tolerance to poor service quality (Accenture, 2011, p. 12; Lervik-Olsen and Johnson, 2003, p. 2 and Entel, Grayson, \& Nathan Huttner, Katzenbach Partners, 2007). The cumulative effect is especially the reason for the importance of delivering consistent and sustainable customer service quality which will receive more attention later on.

Service has unique characteristics and, therefore, needs to be marketed in a unique and special way and also be influenced by management and corporate culture. Products are traditionally marketed by applying the four P's (the marketing instruments) of the marketing mix, namely Product, Place (distribution), Price and Promotion (marketing communications), but the marketing of services require three additional marketing instruments (the extended marketing mix) to be added (Kotler, 1994; Strydom, 2012, p. 244; Cant and van Heerden (eds), 2010, p. 451). These instruments include physical evidence (Zeithaml et al., 2006, p. 27); processes and people (Grönroos 1990 and Strydom, 2012, p. 244) which are basically responsible for conveying the image of service quality and should be integrated with the corporate culture to affect both employees and customers.

\section{The importance of sustainable consistent customer service quality}

Service and service quality forms internally part of most businesses (Kotler and Keller, 2012, p. 356). One bad customer service experience can have to a considerably negative impact on an organization and can haunt an organization for long. Almost $90 \%$ of the time customers will not return if they've had a bad customer service experience (Harris, 2011, p. 2). Multiple episodes of poor service delivery may lead to disconfirmation or general attitude change among the customers and have a significant impact on the reputation of the organization (Awwad and Agti, 2011), but consistency in customer service can obviously build effective long term relationships with the customers.

Businesses realize that good service quality can lead to advantages such as better customer loyalty and profitability according to the well-known Profit Value Chain of Heskett at al. (1977) and Bakhare (2011, p. 48). Service quality can vary according to (Domingo, 2012) the place, the time and the person/s involved in the delivery. To attain consistency over the long term in service delivery is very difficult, yet it is the most important and the most conspicuous (Domingo, 2012). It can become a great sustainable competitive advantage for the business to build customer loyalty and attain higher profitability.

\section{Service delivery by frontline employees}

Services are usually delivered by frontline service employees, representing the first contact with the organization, and can determine a lasting image (Zhou, Yong, and Danling, 2014). Such employees must, therefore, be thoroughly selected, trained and cared for in order to enhance their abilities to perform their jobs to become more effective (Yazdanifard and Jo Ey, 2014, pp. 129-137 and Sohel and Schroeder, 2002, pp. 540-550). But because of the fallibility and inconsistency of the human nature (Markman, 2008) and the unpredictability of influences on them, service 
delivery may not be reliable and sustainable. Management intervention and commitment is needed in terms of aspects such as employee rewards, customer service training, empowerment, customer service orientation and conveying the organization's mission and objectives of the corporate culture to employees (Rod and Ashill, 2010; Yavas, Babakus and Ashill, 2010, p. 373). Even then employees may not be able to deliver optimal service to the customer if they are unhappy and/or unmotivated and they must be motivated and persuaded managers to embrace the quality culture (Heskett et al., 1994). Even well-motivated employees can fail to focus their activities in line with the content of the corporate culture without awareness of the principles of the desired corporate culture (Naicker, 2008, p. 31).

\section{Corporate culture}

Most authors writing about organizational culture regard it as a long term stable, conservative and resistant force that is likely to change only through management intervention (Hatch, 2004, pp. 190-211; Robbins, 2005; El Din Nafie, 2012, p. 84). Some important aspects to sustain long term stability of service quality in a corporate culture are discussed below.

\section{The meaning of corporate culture and the importance thereof}

Organizational culture entails deeply seated (often subconscious) values and beliefs shared by personnel in an organization (Martins and Terblanche, 2003, p. 65). It can be compared to a set of basic best practices that worked so well in the past that they are accepted as part of the corporate culture. This can convey a standard in which things are done or whereby problems should be understood (Coulthard, 2004 and Chingang and Lukong, 2010).

Corporate culture can be seen as a strategic asset, and can be the essence of a "business model" (Flamholtz and Randle, 2011 and Flamholtz and Randle, 2012, pp. 76-94) with which seventy per cent of business leaders agree, while more than 80 per cent believe an organization lacking a highperformance culture is doomed to mediocrity. Similarly, Behar (Behar and Goldstein, 2008), Starbucks International President, has stated in his book about Starbucks that the company's success is about leadership and culture rather than its product; as the title states: "It's not about the coffee"!

It can affect the staff and the workplace and can determine the survival of an organization over the long term derived from the strength and stability of the components of corporate culture providing strength like the strands of a strong cable (Bertels, 2010). These components include shared values; norms of behavior; and symbols and symbolic action and can be summarized as follows (Aaker, 2002 and Aaker, 2011, p. 57, Mobley et al., 2005 and Stock, Six, Zacharias, 2012 and Flamholtz and Randle, 2012, p. 77):

- Shared values (dominant beliefs) necessary to enhance their behavior in a way that is beneficial to the corporate culture. Employees will act accordingly even to gain acceptance and approval from the group (Goldstone, 2007, p. 47).

- Norms of behavior or informal rules of the culture can influence decisions and actions throughout the business.

- Symbols and symbolic action reflect underlying values or realities and tangible expressions of shared realities. Consistent and visible symbols in the work environment can guide employees toward behavior that is appropriate for the situation.

The Dell Computer Company associates good corporate culture with an essential competitive advantage particularly for sustaining high performance (Roger and Meehan, 2007, p. 261).

A Harvard Business School study shows a variety of areas in which companies with the right culture outperformed their counterparts with revenues 4.1 times higher, stock prices 12.2 times higher, and return on investment 15 times higher (Kotter \& Heskett, 2010). A strong positive relationship exists between the kind of marketing culture a service firm has and its degree of marketing effectiveness (Gebauer, Edvardsson and Bjurko, 2010) partly due to a psychological link in the relationship between organizational culture, employee attitude, and performance (Goldstone, 2007, p. 45). According to Goldstone (2007, pp. 43-47), a positive corporate culture can increase organizational effectiveness, productivity, and employee commitment; while also reinforcing the core beliefs embraced by organizational leadership.

Corporate culture as a basis for sustaining customer service quality

A culture of quality is required for success in implementing a quality strategy approach (Hauser 2006 p., 1), because a strong culture is stable and constant and can create behavior consistency through a variety of mechanisms (Goldstone, 2007, p. 34).

Better knowledge of corporate culture drives service-quality excellence and customer satisfaction (Scotti et al., 2007).

According to Roger and Meehan (2007, p. 261), the best companies succeed on two corporate cultural dimensions simultaneously: 
- Unique personality: Every winning culture has a unique personality that cannot be invented or imposed and needs to be discovered from within.

- Six high-performance behaviors: These are the following: high aspirations and a desire to win; an external focus; thinking like owners; biased to action; individuals functioning as teams; passion and energy.

Neither one of these is sufficient, but a combined effect of both produces a winning sustainable culture and what is needed to enhance service quality excellence and a corresponding consumer quality to enhance customer loyalty (Beitelspacher, Richey and Reynolds, 2011).

\section{The relationship between corporate culture, customer service and organizational performance}

Two applicable models include elements explaining the role of corporate culture in service marketing namely the Customer Satisfaction Performance Index and the Profit Service Chain model.

\section{Customer Satisfaction Performance index model (CSP)}

The Customer Satisfaction Performance index (CSP) (Davidson and Kabacoff, 2003) explains the relationships between organizational culture, organizational climate, service quality, customer satisfaction and organizational performance. The combination of components influenced by the organizational culture are described as empowerment and training; organizational climate; operating procedures and resources; and service quality. The effect of these components will give rise to better customer satisfaction and organizational performance.

Service quality and corporate culture were successfully combined in the case of PetroChina where empowerment, training and organizational climate were combined with the purpose to ensure a continuous, stable and healthy development of quality service delivery (PetroChina, 2011). Delivering a high quality and consistent customer experience is also the top driver of loyalty (Kshirsagar \& Thomas, 2011). The CEO of the Dahabshiil Banking Group described their success as 'a direct result of the commitment and dedication of staff worldwide, combined with a unique entrepreneurial corporate culture focusing on consistent delivery of service quality to our customers' (Dababshiil press release, 2016).

\section{The Service Profit Chain and sustainability}

The sustainability element of competitiveness in service organizations is explained by the Service Profit Chain (Lau, 2000, p. 422) attributing the service organization's financial and market performance to its relationships with its customers and employees (Heskett, 2001). Internal service quality serves as the foundation of the model, igniting a chain effect towards an organization's growth and profit (Silvestro, 2002).

The Service Profit Chain establishes relationships between profitability, customer loyalty, employee satisfaction, loyalty, and productivity and can be summarized as follows showing the links of the chain (Heskett et al., 2008):

- Internal quality drives employee satisfaction.

- Employee satisfaction drives employee loyalty.

- Employee loyalty drives employee productivity.

- Employee productivity drives value.

- Value drives customer satisfaction.

- Customer satisfaction drives customer loyalty.

- Customer loyalty drives growth and profitability.

This Profit Service Chain explains in one model what have been discussed so far and clearly indicates the effect of corporate culture on employees, service value and customer satisfaction and loyalty.

Heskett at al. (1997) include many components enhancing corporate culture in the Service Profit Chain such as workplace design, selection and development, rewards and recognition and tools for servicing customers. They further postulate that these elements activate a chain of performance relationships commencing with a virtuous circle of internal service quality; service capability; employee satisfaction and loyalty; productivity and output quality (good service quality). These aspects, in turn, drive service value, customer satisfaction and loyalty, leading to enhanced revenue growth and/or profitability.

Leadership plays a key role in the successful results of the Service Profit Chain. Leaders, who understand the Service Profit Chain, develop and maintain a corporate culture centred on service to customers and fellow employees (Schein, 2004, 2010 and Mgbere, 2009 , p. 380) and service quality (Kasper, 2002). They care about their employees and spend a great deal of time selecting, tracking, and giving them recognition. This is a sharp contrast to many people who take culture as a given and think you can't do anything about it (Heskett et al., 1994, p. 168).

With a clear comprehension of leadership, corporate culture, service quality and eventual profit, attention should also be given to enhancing the consistency and sustainability of the delivery of service quality over the long term based on the inherent stability of corporate culture and how to convey the values of the corporate culture to employees and embed it into the marketing tasks (Kuhlmann, 2010; Sumarto and Subroto A., 2011; and Eustace and and Martins, 2014). 


\section{Corporate culture and sustainability}

Corporate culture has a nature of stability and sustainability (Ramirez, West and Costell, 2013 and Jo Ey and Yazdanifard, 2014). Sustainability is seen by business leaders as central to any business and they believe that sustainability issues will be important to the future success of a business (Accenture, 2011, p. 4). Businesses that have a strong, consistent culture are most effective (Goldstone, 2007, p. 40) and employees and the organization respond in a predictable manner.

The attitude of a business toward quality is important for at least three main reasons relating to efficiency (Popescu and Poanta, 2009, p. 140):

- Effectiveness and cost benefits relating to quality service.

- The pressure exercised by the competition and the development of a sustainable competitive advantage (SCA) as will be discussed later.

- The evolution of client's expectations in terms of service quality.

\section{Building the consistency and sustainability of the corporate culture itself}

Management should impregnate marketing activities with decisions enhancing the desired culture of consistency and consistency in service quality to be made more performance enhancing. Such changes are complex take time and require leadership (Kotter, 1992, p. 12).

The high sustainability organizations are described as those who have embraced a culture of sustainability by adopting a coherent set of corporate policies relating to the environment, employees, community, products and customers. The policies relating to employees include aspects such as a policy for diversity and equal opportunity, work-life balance, health and safety improvement, and favouring internal promotion (Eccles, Loannou and Serafeim, 2012). The ways in which the corporate culture can be imbedded need special attention.

\section{Conveying and embedding the values of corporate culture: the use of internal marketing}

Management can use internal marketing to convey the desired values it wants embed in the corporate culture to the employees (Papasolomou and Vrontis, 2006; Lee and Wen-Jung, 2005; and SantosVijande, Álvarez and Rodríguez, 2012).

Internal marketing can be described as the technique by which leadership can use to persuade and motivate employees towards the effective implementation of corporate and functional strategies and so overcome organizational resistance (Che $\mathrm{Ha}, \mathrm{Abu}$ Bakar and Jaafar, 2007, p. 135). Therefore, a service and customer-oriented culture can be conveyed to the employees by internal marketing (Grönroos, 2000) and is especially needed amongst many ignorant front-line employees (Dobrev, 2012). There exists adequate empirical evidence to support the relationship between internal marketing and business performance (Hwang and Chi, 2005). Internal marketing offers the unique opportunity of embedding the values of the corporate culture practically into training and skills of the employees.

Internal marketing can convey corporate culture over in a bold and convincing way so that the employees will feel part of that culture and of the ventures of the organization sharing the vision of the management. Front-line employees must be well acquainted with portraying the image of good quality in satisfying customers and building strong relationships with them. This depends greatly on effective and successful internal marketing (Dumitrescu and Apostu, 2009, p. 327). One can, thus, regard the primary objective of internal marketing to develop employee awareness of their roles so that the organization can have a lasting relationship with its customers (Dumitrescu, Cetina and Pentescu, 2012). The process of internal marketing can take place in four steps, namely:

1. Establishment of a service culture.

2. Development of a marketing approach in human resource management.

3. Dissemination of marketing information to employees.

4. Implementation of a reward and recognition system.

A strong link has also been found between internal marketing and profits. Hwang and Chi (2005) show that there is empirical evidence to support the relationship between internal marketing and business performance. Further, Awwad and Agti (2011, p. 232) have found that there is a strong relationship between internal marketing and the behavior of employees and organizational commitment and presents a key factor in offering superior services and attain success in the external marketing of an organization (Rayej at al., 2010 and Seyed Javadein at al., 2011).

According to Kotler at al. (2006), there is a difference between conventional and service oriented organizations in terms of the flow and direction of focus and organizational structure differ and indicated in Figure 1. In service culture oriented organizations the flow of information originates at the corporate management and flows towards the customers. Where this management focus is not followed, a weak corporate structure may be the result and will manifest in the following (Kotler et al., 2006):

- Few or no common values or norms will exist as a benchmark.

- Employees may become unsure of their roles.

- Lack of empowerment negatively affects customer service. 

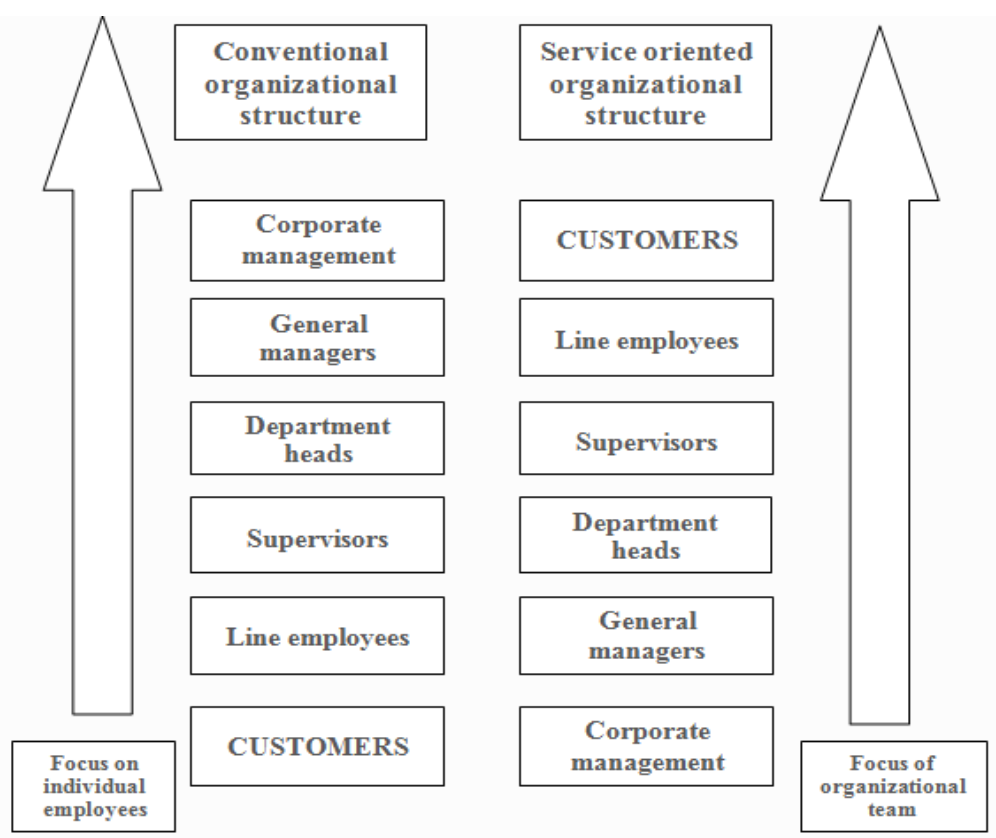

Source: based on Kotler et al. (2006).

Fig. 1. Organizational focuses in internal marketing

The top-down approach is a multidisciplinary approach, because many departments of the organization are involved and not only the marketing department. Tsai and $\mathrm{Wu}$ (2006) suggested that internal marketing should be kept in mind in the design and implementation of human resource management systems so that internal marketing is used within that system to enhance the employees' job satisfaction, motivate employees to achieve organizational goals and promote employee perceptions regarding organizational commitment. The corporate cultural orientation should, therefore, especially include human resource participation with regard to aspects such as job creation, hiring the right people, emphasising teamwork, providing regular information, continuous training and showing each department the importance to work together to provide quality service.

The implementation of the corporate culture must be goal oriented, so that the behaviors among the employees correspond with the original intention of the investment in internal marketing activities within the organization, because internal marketing has a positive direct effect on organizational commitment of the employees (Awwad and Agti, 2011, p. 232). Human resources can then create more emotionally attached employees believing in "their" organization where they want to remain employed, by providing effective training, a fair reward system, a positive interaction between employees within the organization and sharing vision among them.

\section{Practical implementation}

To ultimately provide a better service experience for customers, more attention should be directed towards enhancing organisational commitment among personnel, with a focus on the effective criteria of internal marketing (Awwad and Agti, 2011, p. 232).

Telkom, the oldest fixed line telephone company in South Africa, said "Culture is important, because it powerfully influence the behavior of employees; it is difficult to change; and because it's near invisibility makes it hard to address directly" (Singleton, 2004). Telkom addressed the following core values of their value system to bridge the culture gap and provide motivation for quality customer service: we value people and their diversity; we are performance driven; we are customer focused; we create shareholder value; we are a model corporate citizen; and act with integrity in everything (Singleton, A., 2004).

Practical steps by Standard Bank (South Africa) in this regard were described in terms of practical outcomes relating to the practical application of their corporate culture, namely (Standard Bank Sustainability Report, 2014 and Reynolds-de Bruin, 2013):

- Front-line employees provide an excellent customer experience.

- Clear customer service goals are continuously communicated through various channels to employees.

- Visible leadership is provided in driving their service culture by management taking a prominent role and dedicates time to pay visits across the country and interacting with employees and customers. 
A good example of a practical application of internal marketing on different hierarchical levels in a business was found in the case of the Nstar (a mega USA energy supply company) (Schweiger, n.d.). Nstar's internal marketing is clearly based on and derived from the mission and culture of the business. They presented it in a layered approach to reflect the golden line of customer service culture. The aims of each of the levels start with the slogan: "Building a company we are proud to own" and each layer (or level) flows from the mission statement in layer 1: "We are in the business of serving or customers well".

Layer 1 links customer service to the mission and corporate culture.

Layer 2 expresses the mission statement in terms of culture and strategy objectives.

Layer 3 links mission and corporate culture with management level success criteria relating to a dependable service.
Layer 4 links the mission and corporate culture to the performance of specific tasks with the slogan "It starts with us".

Dunnett (2007, p. 44) suggests that the "caliber" of services that the customer receives will depend on "the corporate culture's ability to motivate its members and gain commitment from them to serve the customers in the intended way".

\section{Conclusion}

A well-planned and maintained corporate culture, based on quality service delivery goals, can enhance the stability and sustainability of the delivery of service quality. Top management should take the initiative to plan and manage such a corporate culture. Service quality delivery involves inputs from the different functional areas and levels. Employees must be convinced to deliver constant good service quality, because they want to get feeling of fulfilment and self-motivation derived from that in the created culture.

\section{References}

1. Accenture. (2011). UN Global Compact-Accenture CEO Study towards a new era of sustainability in the banking industry. UN Global Compact-Accenture CEO Study.

2. Ahmed, P.K., Rafiq M. (2002). Internal marketing. Tools and concepts for Customer-focused management. Oxford: Butterworth-Heinemann.

3. Aaker, D.A. (2002). Building strong brands. NY. Simon and Shuster.

4. Aaker, D.A. (2011). Building strong brands. NY: Siman and Shuster.

5. Awwad, M.S. \& Agti, D.A.M. (2011). The impact of internal marketing on commercial banks' market orientation, International Journal of Bank Marketing, Vol. 29 No. 4, pp. 308-332

6. Bakhare, S.R.S. (2011), The Impact of Employee Satisfaction on Customer Delight, Service Quality and Profitability of the Firm, Anvesha, 4.2 (Jul-Dec 2011), pp. 44-53.

7. Banks, J.A., Banks \& McGee, C.A. (1989). Multicultural education. Allyn \& Bacon, Needham Heights, MA

8. Beaujean, M., Davidson, J. \& Madge, S. (2006). The moment of truth in customer service, McKinsey Quarterly, Number 1, 2005, pp. 62-73.

9. Behar, H. \& Goldstein, J. (2008). It's Not About the Coffee, Portfolio, New York, NY

10. Beitelspacher, L.S., Richey, R.G. \& Reynolds, K.E. (2011). Exploring a new perspective on service efficiency: service culture in retail organizations, Journal of Services Marketing, Vol. 25 Iss: 3, pp. 215-228.

11. Bertels, S. (2010). Embedding sustainability in organizational culture: A How-to Guide for Executives. Network for Business Sustainability.

12. Cambra-Fierroa, J., Melero-Polob and Vázquez-Carrascoa, I.R. (2014). The role of frontline employees in customer engagement, Spanish Journal of Research in Marketing ESIC (Revista Española de Investigación en Marketing ESIC).

13. Cant, M.C. \& Van Heerden, C.H. (2012). Marketing Management. Cape Town: Juta.

14. Cerasale, M.V. (2005). Business Solutions on Demand: How to Transform From a Product-led to a Service-led Company. Kogan Page Publishers, London.

15. Che Ha, N., Abu Bakar, R, and Jaafar, S.I.S. (2007). Internal marketing issues in service organizations in Malaysia, International Review of Business Research Papers, Vol. 3 No. 5, November, pp.134-145.

16. China Construction Bank. (2007). Emphasis on interaction successful transformation of CCB Tianhe sub-branch. Internal research paper. Online at http://www.ccb.com/en/announcement/1190766891100.html. Accessed 1 September 2012.

17. Chingang, N.D. \& Lukong, P.B. (2010). Using the SERVQUAL Model to assess Service Quality and Customer Satisfaction. An Empirical study of grocery stores in Umea. Unpublished Master's thesis. Umea. University of Umea. Sweden.

18. Coulthard, L.J.M. (2004). Measuring service quality: A review and critique of research using SERVQUAL, International Journal of Market Research, Vol. 46 No. 4, pp. 479-497.

19. Dababshiil press release. (2016). Dababshiil bank. Dubai. Online at http://dj.dahabshiil.com/news/press-releasesarticles.html. Accessed 11 April 2016. 
20. Davidson, M.C.G. and Kabacoff, L.F. (2003). Does organizational climate add to service quality in hotels? School of Hotel Restaurant and Tourism Administration, Volume: 15 Issue: 4, The University of New Orleans, New Orleans, Louisiana, USA, pp. 206-213.

21. Dumitrescu, L. and Apostu, C. (2009). Marketing and the quality of services. Ed. Expert, Bucureti, pp. 328-329

22. Dumitrescu, L., Cetină, I., Pentescu, A., Denison, D.R. and Neale, W. (2000). The Denison organizational culture survey, Facilitator's Guide. Online at http://www.denisonconsulting.com. Accessed 15 November 2012.

23. Dobrev, Z. (2012). Are banks really different? How do you differentiate beyond just the slogan? Beyond Philosophy, 15 Aug 2012. Online at http://www.beyondphilosophy.com/blog/are-banks-really-different-how-doyoudifferentiate. Accessed on 28 Aug 2012.

24. Domingo, R.T. (2012). Consistency in service quality. Business Management articles. RDT.com. http://www.rtdonline.com/BMA/CSM/9.html. Accessed at 25 November 2012.

25. Dunnett, A.J. (2007). The role of organizational culture in customer service, The Business Review, Vol. 7, No. 1, pp 38-44.

26. Deal, T. \& Kennedy, A. (1982). Corporate cultures. Reading, MA: Addison-Wesley.

27. Eccles, R.G., Loannou, I. \& Serafeim, G. (2012). The impact of a corporate culture of sustainability on corporate behavior and performance. Working paper. 9 May 2012. Harvard Businesses School.

28. Ekmekci, O. (2009). The role of frontline employees in building sustainable customer service SAM Advanced Management Journal. Autumn 2009. Online at http://findarticles.com/p/articles/mi_hb6698/is_4_74/ ai_n52942973/. Accessed on 17 August 2011

29. Entel, T., Grayson, S. \& Nathan Huttner, Katzenbach Partners. (2007). The Empathy Engine: Turning Customer Service Into a Sustainable Advantage. Booz \& Co. The Katzenbach Center. Online at http://www.booz.com/media/uploads/The_Empathy_Engine.pdf. Accessed on 12 May 2012.

30. Eustace, A and Martins, N. (2014). The role of leadership in shaping organisational climate: An example from the fast moving consumer goods industry, SA Journal of Industrial Psychology/SA Tydskrif vir Bedryfsielkunde, 40(1), Art. \#1112, 13 pages. http://dx.doi.org/10.4102/ sajip.v40i1.1112 Online at http://www.scielo.org.za/ pdf/sajip/v40n1/03.pdf [accessed on 18 May 2016]

31. Flamholtz, E.G. and Randle, Y. (2011). Corporate Culture: The Ultimate Strategic Asset. Stanford, CA: Stanford University Press.

32. Flamholtz, E. and Randle, Y. (2012). Corporate culture, business models, competitive advantage, strategic assets and the bottom line, Journal of HRCA: Human resource, costing and accounting.

33. Ghandi, S. and Kang, L.S. (2012). Customer satisfaction, its antecedents and linkage between employee satisfaction and customer satisfaction: a study, Asian Journal of Business and Management Sciences, 11.

34. Gebauer, H., Edvardsson, B., Bjurko, M. (2010). The impact of service orientation in corporate culture on business performance in manufacturing companies, Journal of Service Management, 21 (2), pp. 237-259.

35. Goldstone, B.K. (2007). The relationship between traits of organizational culture and job satisfaction within the healthcare setting. Unpublished Phd Thesis. Walden University.

36. Grönroos, C. (1999). Service management and marketing: managing the moments of truth in service competition, Lexington Books.

37. Grönroos, C. (2000). Service Management and Marketing: A Customer Relationship Management Approach. NY: Wiley.

38. Harris Interactive. (2011). 2011 Customer Experience Impact Report. Getting to the Heart of the Consumer and Brand Relationship. Commissioned by RightNow (acquired by Oracle in March 2012).

39. Hatch, M.J. (2004). Dynamics in organisational culture, in Poole, M.S. \& Van de Ven, A. (eds.). New direction in the study of organizational change and innovation processes. New York: Oxford University Press. pp. 190- 211.

40. Hauser, R. (2006), "Is service quality and culture: an empirical investigation The Journal of Computer Information Systems, Fall 2006.

41. Heathfield, S.M. (2011). Culture: Your environment for people at work: What is organizational culture? Human Resources. Online at http://humanresources.about.com/od/organizationalculture/a/culture.htm.

42. Heskett, J.L. (2001). Planet feedback: The voice of one... the power of many, Case no. 9-901. Harvard Business Review, March/ April. 2001

43. Heskett, J.L., Jones, T.O., Loveman, G.W., Sasser, W.E. Jr. \& Schlesinger, L.A. (1994). Putting the Service-Profit Chain to Work, Harvard Business Review, March-April 1994, p. 168.

44. Heskett, J.L., Jones, T.O., Loveman, G.W., Sasser, W.E. Jr. \& Leonard A. Schlesinger. (2008). Putting the serviceprofit chain to work, Harvard Business Review, July 2008. Available at: http://hbr.org/2008/07/putting-theservice-profit-chain-to-work/ar/1.

45. Hwang, I and Chi, D. (2005). Relationships among internal marketing, employee satisfaction and international hotel performance: An empirical study, International Journal of Management, 22 pp. 285-293.

46. Jo Ey, C. and Yazdanifard, R. (2014). The Impact of Employee's Satisfaction on Company's Well-being and Sustainability of the Company in the Long Run, Journal of Research in Marketing,Volume 3, No. 1, August 2014.

47. Kasper, H. (2002). Culture and leadership in market-oriented service organisations, European Journal of Marketing, Vol. 36 Iss: 9/10, pp. 1047-1057.

48. Kasper, H., Van Helsdingen, P. \& De Vries, V. (1999). Services Marketing Management. John Wiley and Sons, NY.

49. Kshirsagar, A. \& Thomas, R. (2011). The economic times. Quality services key for banks to retain loyal customers. 21 July 2011. Online at http://economictimes.indiatimes.com/opinion/policy/quality-services-key-forbanks-to-retain-loyal-customers/articleshow/9305893.cms. Accessed 5 August 2011. 
50. Kotter, J.P. (1992). Corporate culture and performance. NY: The Free Press.

51. Kotler, P., Bowen, J.T. \& Makens, J.C. (2006). Marketing for hospitality and tourism. (4th ed.). Upper Saddle River: Prentice-Hall.

52. Kotter, J.P. (2008). Corporate culture and performance. NY: The Free Press.

53. Kotter, J. \& Heskett, J. (2010). Corporate Culture and Performance, Harvard Business School Smartblog on leadership, Oct 2010.

54. Kotler, P \& Keller, K.L. (2012). Marketing Management. NY: Prentice-Hall.

55. Kuhlmann, A. (2010). Culture-driven leadership, Ivey Business Journal, Issues: March / April 2010.

56. Lau, R.S.M. (2000). Quality of work life and performance An ad hoc investigation of two key elements in the service profit chain model, International Journal of Service Industry Management, Vol. 11 No. 5, pp. 422-437.

57. Lee, Chuan, Wen-Jung, Chen. (2005). International Journal of Management, 22 (4), pp. 661-672.

58. Lervik-Olsen, L. \& Johnson, M.D. (2003). Service equity, satisfaction, and loyalty: From transaction-specific to cumulative evaluations, Journal of Service Research, (5) (3), pp. 184-195. Retrieved 21/01/2016,

59. Liang, Rong-Da, Tseng, Hsing-Chau, Lee, Yun-Chen (2010). International Journal of Marketing Studies, 2(2), pp. 67-74.

60. Malik, S.U. (2012). Customer Satisfaction, Perceived service quality and mediating role of perceived value, International journal of marketing studies, Vol. 4, No. 1, February 2012.

61. Markman, A. (2008). Unpredictability is in our nature. Online at www.psychologytoday.com/blog/ulteriormotives/200811/unpredictability-is-in-our-nature. Accessed 8 February to 2016.

62. Martins, E.C. \& Terblanche F. (2003). Building organisational culture that stimulates creativity and innovation, European Journal of Innovation Management, Vol.6 No.1, 2003.

63. Mgbere, O. (2009). Journal of Strategic Management Education, 5.3/4 (2009), pp. 187-201.

64. Mobley, W.H., Wang, L. \& Fang, K. (2005). Organisational culture: measuring and developing it in your organization, Ceibs knowledge, June 2005. Available at www.ceibs.edu/knowledge/ob/92_97.shtml (accessed 14 July 2010).

65. Naicker, N. (2008). Organizational culture and employee commitment: a case study. Unpublished MAdmin. Durban University of Technology: 31.

66. El Din Nafie, R.M. (2012). National Culture Transformation and Its Impact on Multinational Corporate Culture: Case Study of Egypt, World Journal of Social Sciences, Vol. 2. No. 1, January 2012. pp. 84-94.

67. Olsen, L.L. \& Johnson, D. (2003). Service Equity, Satisfaction, and Loyalty: From Transaction-Specific to Cumulative Evaluations, Journal of Marketing Research, February 2003, Vol. 5 No. 3, pp 184-195.

68. Owen, K., Mundy, R., Guild, W. and Guild, R. (2001). Creating and sustaining the high performance organization, Managing Service Quality, Vol. 11, No. 1, pp. 10-21. MCB University Press. ISSN 0960-4529.

69. Papasolomou, I. \& Vrontis, D. (2006). Building corporate branding through internal marketing: the case of the UK retail bank industry, Journal of Product \& Brand Management, 15 (1), pp. 37-47

70. Parasuraman, A. \& Zeithaml, V. (2006). Understanding and improving service quality: a literature review and research agenda. In B. Weitz \& R. Wensley (Ed.), Handbook of Marketing. London: Sage Publications.

71. Parasuraman, A., Zeithaml, V.A. \& Berry, L.L. (1985). A Conceptual Model of Service Quality and Its Implications for Future Research, Journal of Marketing, Vol. 49, No. 4, pp. 41-50.

72. Parasuraman, A., Zeithaml V.A. \& Berry, L.L. (1988). SERVQUAL: A multiple-item scale for measuring consumer perceptions of service quality, Journal of Retailing, Vol. 64, No. 1, pp. 12-40.

73. PetroChina International Co., Ltd. (2011). Corporate culture. Spirit and philosophy. Online at http://intl.petrochina.com.cn/pic/petrochinaintl/Corporate+culture/. Accessed on 22 August 2011.

74. Popescu, J. \& Poanta, D. (2009). The banking marketing in sustainability conditions. Finance - Challenges of the Future University of Craiova. Financial Management Faculty, Romanian Banking Institute Year VIII, No. 9/2009.

75. Pritchard, M. and Silvestro, R. (2005). Applying the service profit chain to analyse retail performance: The case of the managerial strait-jacket? The International Journal of Service Industry Management, Volume: 16, Issue: 4.

76. Rafiq, M. and Ahmed, P.K. (1998). A customer-oriented framework for empowering service employees, Journal Of Services Marketing, Vol. 12, No. 5, pp. 379-94.

77. Rafiq, M. and Ahmed, P.K. (2000). Employee Satisfaction Measurement - Part of Internal Marketing, Journal of services marketing, vol 14, no.6, pp. 449-462.

78. Ruchlin, H.S. Dubbs, N.L. and Callahan, M.A. and Fosina, M.J. (2004). The Role of Leadership in Instilling a Culture of Safety: Lessons from the Literature, Journal of Healthcare Management, 49(1) (Jan/Feb 2004), pp. 4758; discussion 58-9.

79. Rahman, M.S., Khan, A.H. and Haque, M. (2012). Conceptual Study On The Relationship Between Service Quality Towards Customer Satisfaction: SERVQUAL and Grönroos's Service Quality Model Perspective, Asian Social Science, Vol. 8, No. 13, pp. 201-210, November.

80. Ramirez, B., West, D.J., Costell, M. (2013). Development of a culture of sustainability in health care organizations, Journal of Health Organization and Management, 27(5), pp. 665-72.

81. Seyed Javadein, S.R., Rayej, Estiri, H.M. and Ghorbani, H. (2011). The Role of Internal Marketing in Creation of Sustainable Competitive Advantages, Trends in Applied Sciences Research, 6, pp. 364-374.

82. Rayej, H., Seyed Javadein, S.R., Yazdani, H. and Miri, S.A. (2010). Relationship between internal marketing, OCB and service quality. Modares J.

83. Robbins, S.P. (2005). Organisational behaviour. 11th edition. Prentice Hall Inc. 
84. Rod, M. and Ashill, N.J. (2010). Management commitment to service quality and service recovery performance. A study of frontline employees in public and private hospitals Management commitment to service quality and service recovery performance, International Journal of Pharmaceutical and Healthcare Marketing, Vol. 4, No. 1, pp. 84-103.

85. Roger, P. and Meehan. (2007). Business Strategy Series, Vol. 8, Iss. 4, p. 261.

86. Schein, E.H. (2004). Organisational culture and leadership. San Francisco: John Wiley \& Sons.

87. Schein, E.H. (2010).Organisational culture and leadership. San Francisco: John Wiley \& Sons.

88. Schneider, B., Gunnorson, S.K. and Niles-Jolly, K. (1994), Creating the climate and culture of success, Organizational Dynamics, pp. 17-29.

89. Scotti, D., Harmon, J., Behson, S. and Messina, D. (2007). Links among high-performance work environment, service quality, and customer satisfaction: an extension to the healthcare sector, Journal of Healthcare Management, Vol. 52, No. 2, pp. 109-125.

90. Silvestro, R. (2002). Dispelling the Myth: employee satisfaction and loyalty drive service profitability, International Journal of Operatiions and Production management, Vol 22, Number 1, pp. 30-49.

91. Singleton, A. (2004). Culture change through leadership. PowerPoint presentation for Telkom at the Bankseta Conference 2004. Available at www.bankseta.org.za/downloads/conference/Amanda_Singleton.ppt.

92. Sohel, A. and Schroeder, R.G. (2002). The importance of recruitment and selection process for sustainability of total quality management, The International Journal of Quality \& Reliability Management, 19(5), p. 540.

93. Stock, R.M., Six, B. \& Zacharias, N.A. (2012). Linking multiple layers of innovation-oriented corporate culture, product program innovativeness, and business performance: a contingency approach, /accepted: 22 May 2012, Journal of the Academy of Marketing Science 2012. Online at http://www.springerlink.com/ content/23171v06354g28u0/. Accessed on 1 October 2012.

94. Strydom, J.W. ed. (2012). Introduction to marketing management. Cape Town: Juta.

95. Suksom, S. \& Lumyong, R. (2009). Service Quality of Thai Travel Agency, Thailand Resor AB, in Sweden. Master's Thesis MIMA-International Business and Entrepernuership School of Sustainable Development of Society and Technology Mälardalen University. 23th November 2009.

96. Sumarto and Subroto, A. (2011). Organizational Culture and Leadership Role for Improving Organizational Performance: Automotive Components Industry In Indonesia, International Journal of Innovation Management and Technology, Vol. 2, No. 5, October.

97. Tsai, Y. \& Wu, S.W.S. (2006). Internal marketing, organizational commitment and service quality. Published in conference proceedings for the International Conference on Service Systems and Service Management, 2006. Vol 2, 25-27 Oct., pp. 1292-1298.

98. Wolak, R., Kalafatis, S. \& Harris, P. (1998). An Investigation Into Four Characteristics of Services, Journal of Empirical Generalisations in Marketing Science, Volume Three.

99. Yavas, U., Babakus, E. \& Ashill, N.J. (2010). Testing a branch performance model in a New Zealand bank, Journal of Services Marketing, 24 April 2010, pp. 369-377.

100. Yesilada, F. \& Directör, E. (2010). Health care service quality: A comparison of public and private hospitals, African Journal of Business Management, Vol. 4(6), pp. 962-971.

101. Wisdom on Demand, n.d. Online at www.iwise.com. Accessed on 21 November 2012.

102. Yazdanifard, R. and Jo Ey, C. (2014). The impact of employee's satisfaction on company's well-being and sustainability of the company in the long run, Journal of Research in Marketing, 3 (1), August 2014, p. 239.

103.Zeithaml, V.A. \& Bitner, M.J. (2003). Services Marketing: Integrating Customer Focus Across The Firm. McGraw Hill, New York: McGraw-Hill / Irwin: 267.

104.Zeithaml, V.A., Bitner, M.J. \& Gremler, D.D. (2006). Services Marketing: Integrating Customer Focus across the Firm. $4^{\text {th }}$ ed. New York: McGraw.

105.Zhou, L., Yong, L. \& Danling, L. (2014). The Mediating Role of Job Burnout in the Relationship between Role Conflict and Job Performance: An Empirical Research of Hotel Frontline Service Employees in China, International Journal of Psychological Studies, Vol. 6, No. 3. 